patient 2. Bronchodilation as the underlying mechanism is unlikely in the two cases.

$\mathrm{PGI}_{2}$, when intravenously infused, has a short half life of 2-3 minutes. After clinical use for more than 10 years, no toxic side effects have been reported. Therefore the risk of inhalative administration appears to be low. Devices for drug inhalation in ventilated patients are commonly available.

Nitric oxide seems to be becoming the drug of choice for pulmonary hypertension in ventilated patients. Nevertheless its use is not free of hazards: a fatal case after accidental overdose has been described. Furthermore, its use requires special equipment for monitoring.

Because of the lack of any known toxicity for $\mathrm{PGI}_{2}$ and its uncomplicated mode of inhalative application it may be a useful alternative. Further controlled trials of aerosolised $\mathrm{PGI}_{2}$ are warranted in neonates with pulmonary hypertension, especially when intrapulmonary shunting contributes to hypoxaemia.

1 Roberts JD, Polaner DM, Lang P, Zapol WM. Inhaled nitric oxide in persistent pulmonary hypertension of the newborn. Lancet 1992; 340: 818-9.

2 Wessel DL, Adatia I. Thompson J, Kulik TJ. Inhaled nitric oxide and acetylcholine in the evaluation of pulmonary hypertension and endothelial function after cardiohypertension and endothelial function after cardiopulmonary bypass. Circulation 1993; 88 (part 1): 2128-38.
3 Welte M, Zwissler B, Habazettl H, Messmer K. PGI 2 aeroso versus nitric oxide for selective pulmonary vasodilation in hypoxic pulmonary vasoconstriction. Eur Surg Res 1993 25: $329-40$.

4 Walmrath D, Schneider T, Pilch J, Grimminger F, Seegar W. Aerosolized prostacyclin in adult respiratory distress syndrome. Lancet 1993; 342: 961-2.

5 Rossaint R, Falke KJ, López F, Slama K, Pison U, Zapol WM. Inhaled nitric oxide for the adult respiratory distress WM. Inhaled nitric oxide for the adult respiratc

6 Hardy CC, Bradding P, Robinson C, Holgate ST Bronchoconstrictor and anti-bronchoconstrictor properties of inhaled prostacyclin in asthma. $\mathcal{F}$ Appl Physiol 1988; 64 1567-74.

\title{
Hydrops fetalis caused by a blood group antibody usually undetected in routine screening
}

\author{
J Smoleniec, N Anderson, G Poole
}

\begin{abstract}
A case of isoimmunisation in pregnancy caused by antibodies to the $K \mathrm{p}^{\mathrm{a}}$ red blood cell antigen is described. The preceding pregnancy had resulted in fetal hydrops for which no cause was found as the antibody screening cells used to investigate the fetal hydrops were $K^{a}{ }^{a}$ negative. This case emphasises the importance of serological screening at a reference laboratory for low frequency red cell antigens before a diagnosis of non-immune hydrops is made.
\end{abstract}

(Arch Dis Child 1994; 71: F216-F217)

The Penny $\left(K \mathbf{p}^{\mathrm{a}}\right)$ and Rautenberg $\left(\mathrm{Kp}^{\mathrm{b}}\right)$ antigens are part of the Kell blood group system. The incidence of $\mathrm{Kp}^{\mathrm{a}}$ is $2 \%$ in the white population. ${ }^{1}$ Anti-Kp ${ }^{\mathrm{a}}$ is known to cause haemolytic disease of the newborn but is not usually associated with hydrops fetalis or haemolysis severe enough to require intrauterine transfusion. $^{2}$

Bristol

J Smoleniec

Regional Transfusion Centre, Bristol

N Anderson

G Poole

Correspondence to Mr J Smoleniec,

St Michael's Hospital,

St Michael's Hill,

Bristol

BS2 8EG.

Accepted 23 May 1994
Her first preonancy seven years previo resulted in a normal vaginal delivery. Five years later she had a spontaneous abortion at
7 weeks' gestation. In the third pregnancy, intrauterine death of the fetus occurred at 17 weeks' gestation. The fetus was hydropic but no fetal cells were obtained for red cell grouping or antibody identification. No irregular antibodies were found in the maternal serum, and no other cause for the hydrops was identified. She had no history of previous blood transfusion.

Her red cells were phenotyped as group A $\mathrm{Rh} \mathrm{D}$ positive, $\mathrm{Kp}(\mathrm{a}-\mathrm{b}+)$. Her husband's red cells were phenotyped as group $\mathrm{O} R \mathrm{Rh} D$ positive, $\mathrm{Kp}(\mathrm{a}+\mathrm{b}+)$; being heterozygous for the $\mathrm{Kp}^{\mathrm{a}}$ antigen, and therefore giving the baby a $50 \%$ chance of being $\mathrm{Kp}^{\mathrm{a}}$ positive. The titre of anti-Kp $\mathrm{K}^{\mathrm{a}}$ was 256 at 17 weeks' gestation, and conservative management was advised with weekly ultrasound scanning for fetal hydrops and maternal blood sampling every two weeks. At 24 weeks' gestation the titre of anti- $\mathrm{Kp}^{\mathrm{a}}$ had risen to 1000 and at 25 weeks, early fetal ascites was noted by ultrasound scanning. Intrauterine fetal blood sampling revealed a severely anaemic fetus with a haemoglobin concentration of $40 \mathrm{~g} / \mathrm{l}$. The direct Coombs test (direct antiglobulin test) was positive and the fetal cells were typed as group $O \mathrm{Rh} D$ positive, $\mathrm{Kp}(\mathrm{a}+\mathrm{b}+)$. Spectrophotometric measurement of the deviation in optical density of the amniotic fluid at $450 \mathrm{~nm}(\Delta 450)$ was unhelpful in predicting the severity of the fetal anaemia.

The pregnancy was managed with regular intrauterine transfusions up to 32 weeks' 
gestation. Labour was induced at 35 weeks' gestation resulting in a live male infant.

The cord blood was group $\mathrm{O} R \mathrm{R} \mathrm{D}$ positive, direct Coombs test positive. The Kleihauer test showed $18 \%$ fetal cells and the haemoglobin was $136 \mathrm{~g} / 1$. A month after delivery the direct Coombs test was positive and a topup transfusion was given. The infant required a further top-up transfusion at 2 months of age.

\section{Discussion}

The low incidence of the $\mathrm{Kp}^{\mathrm{a}}$ antigen in the population means that red cell screening reagents for routine antenatal screening do not usually carry the $\mathrm{Kp}^{\mathrm{a}}$ antigen. It was fortuitous that the cells in use at the time of this patient's serological screening at 17 weeks' gestation expressed the $\mathrm{Kp}^{\mathrm{a}}$ antigen and that the antibody was detected early enough to allow planned management of the pregnancy.

The screening red cells in use at the time of the previously affected pregnancy were $\mathrm{Kp}(\mathrm{a}-\mathrm{b}+)$ and the antibody would therefore not have been identified during this investigation.

The measurement of optical density of amniotic fluid is a measure of the bilirubin content of the fluid. The fact that the $\Delta 450$ of the amniotic fluid was unhelpful in predicting the severity of anaemia was not unexpected as antibodies to the Kell antigens are thought to have a disproportionate effect on the fetal red cell precursors ${ }^{3}$ rather than causing haemolysis of red blood cells.

We conclude that in cases of hydrops fetalis where no serological cause is found, serum should be sent to a reference centre for investigation using a panel of red cells expressing low frequency antigens. Identification of antibodies to these antigens allows improved management, as in this case, and counselling regarding future pregnancies. Furthermore, such referral would be likely to identify cases which are otherwise labelled as non-immune hydrops of unknown cause. ${ }^{45}$

The authors wish to thank Dr P Kingston and Mr M Read of the Gloucester Royal Infirmary for permission to report this case.

1 Mollison PL, Engelfriet CP, Contreras M. In: Blood transfusion in clinical medicine 9th Ed. Oxford: Blackwell fusion in clinical medicine. 9th Ed.

2 Bowman JM. Treatment options for the fetus with alloimmune haemolytic disease. Transfus Med Rev 1990; 4: 191-207.

3 Mollison PL, Engelfriet CP, Contreras M. In: Blood transfusion in clinical medicine. 9th Ed. Oxford: Blackwell Scientific Publications, 1992: 582.

4 Machin GA. Hydrops revisited. Am f Med Genet 1989; 34: 366-90.

5 Holzgreve W, Curry CJR, Golbus MS, Callen TW, Filly RA, Smith JC. Investigation of non-immune hydrops fetalis. Am F Obstet Gynecol 1984; 150: 805-12. 